\title{
NURSING HUMAN RESOURCE DEVELOPMENT IN MONGOLIA
}

\author{
Namjilmaa G., Ganbat B., Oyunbileg Sh., Naranbaatar N. \\ National University of Medical Science, Mongolia
}

DOI: https://doi.org/10.31435/rsglobal_conf/30112020/7273

Abstract. There is a need for a policy to modernize Mongolia's nursing care in rural areas, and to allocate and retain nurses. Nursing human resource growth is averaging 2.01 percent per year. The number of nurses working in rural areas has decreased by 21.4 percent over the last 19 years. There is a need to reflect cross-sectoral cooperation and the roles, activities and participation of policy stakeholders in the implementation of nursing human resource policy.

Keywords: nursing, human resource, allocation, rural area, policy.

Background. By 2019, 12,773 nurses are working in our country and 46.7 percent of them work in rural areas, and 9,875 are working directly in medical services. In rural hospitals, the workload of nurses is so high and we need to meet the work to international standards based on medical science. The supply of nurses does not meet the required standards, especially in rural areas, nursing services cannot meet the demand of care is limited in terms of quantity and quality, and it depends on a huge amount of transition of nurses.

Purpose. The survey was conducted to analyze the current situation of allocation and migration of nursing human resources in rural areas.

Methods. Evidence-based and descriptive research models identified nursing human resources reports, data, and statistics. The research is provided according to the research ethics committee by permission of the Research Ethics Committee №13-1A meeting of the Research Ethics Committee №13-03 / 1A. The survey was conducted with the approval of the meeting and the card was filled out with the signature of each person. From each stages the list of nurses made required collections by definite selection and collected defined numbers randomly. Research design and scope: A total of 560 nurses working in rural areas, including 10 aimags in 4 economic regions of Mongolia, were selected from two-level hospitals. By the research of documents: The information has been taken from documents, legal acts, orders and rules and information of government organizations. By Quantitative research: Here involved challenges to nursing human resources and its distribution and study ways identification of improvement nursing human resource challenges. In this research involved 134 nurses as representation of total nurses. According to guide lines held 15 times discussions and provided 9 discussions intercom hospitals' nurses and provided 7 discussions in aimag hospitals' nurses. We collected information by purposive sampling and quota sampling and involved in significance level of 5 percent and sampling force is involved $80 \%$ and participated totally 170 organizations and 27 hospitals of 1and 2nd stage. Based on the guidelines of the interview questions, the participants were guided by the principle of equal participation in order to reveal the opinions, suggestions and opinions of the participants through discussion. The interview lasted 60 minutes.

Analyses. Focus group discussions were matched with keywords. The sub-headings and guided questions are grouped by region (review of sub headings and guided questions). Identify key aspects from guided questions content, select the quotes and key comments / recommends, and make a report. analytic summary). Analyze and summarize documents Policy documents were analyzed by analyzing and summarizing the documents. In addition, capacity, structure, and management decisions in nursing human resource stratification were compared by comparing health indicators. The future direction of nursing human resources was determined by extrapolation.

Results. Current status of policy implementation.

The analysis of the implementation of the policy paper shows that there is no causal analysis of human resource policies, strategies in the areas of health, education, labor, and social protection, which are slow to implement, whose participation is weak, and whether there is duplication of functions. The parties do not know exactly how to participate in the policy, which creates conditions for weak cross-sectoral cooperation and policy implementation from top to bottom. This is: The policy 
to develop human resources in the health sector in 2004-2013 was implemented incompletely by 2941 nurses, "medium-term human resource outlook for the health sector 2005-2015" policy was underimplemented by 2317 nurses, the government's health sector policy for 2012-2016 has not been achieved, the "State Health Policy" aims to make the ratio of doctors and nurses 1: 1.6 by 2021 and $1: 2$ by 2026 , but the reality is $1: 1.1$, according to the standard approved in 2017 , there will be $2.0-2.5$ nurses per doctor and 0.5-1 assistant nurses per 4 nurses, which shows that there is a shortage of 2434.5 nurses in rural areas, out of 1623.

Comparing the distribution of nurses working in rural hospitals with the lower limit of the standard, the average number of nurses in the aimags is 315.3 and the number of nurses is understaffed from 1623 to 2434.5 . The number of nurses will be 12,773 in 2019, and a dynamic analysis of the population shows that the human resources for nursing have increased by 3.4 percent over the past year.

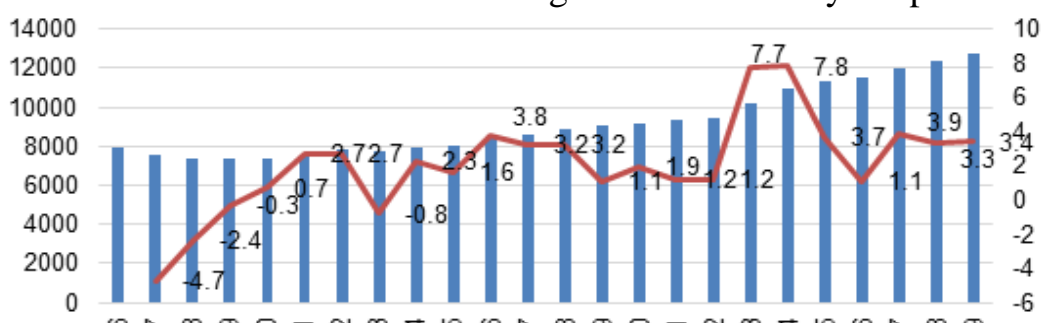

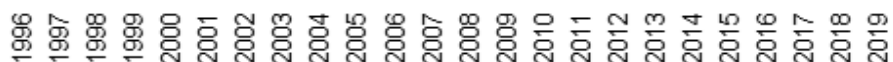

Fig.1. Current supply and growth trends of nurses

Overall, the consolidated trend analysis shows that the number of nurses increases by an average of 2.01 percent per year, which is very low. The highest increase in the number of nurses was in 2014, when it increased by 7.8 percent, and the lowest in 1997, when it decreased by 4.7 percent. The average of the last 5 years is estimated to be 12772.9 nurses in 2019, indicating that the current (12773 nurses) can be used to extrapolate future human resource trends. In 2020, there will be $13,041.07$ nurses, and in 2030, there will be $16,156.6$ nurses.

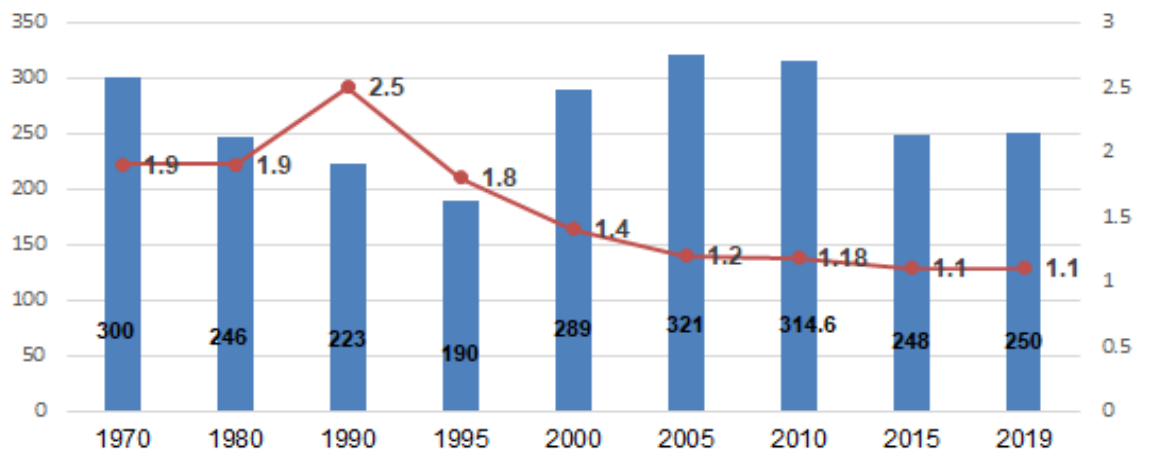

Fig.2. Population per nurse and doctor-nurse ratio

In 1985, there were 2.5 nurses per doctor, compared to 1.1 nurses per doctor in 2015 , and the situation will remain the same in 2019. The highest number of nurses per 10,000 population was 52.6 in 1990, while the lowest was 31.1 in 2000, and the number of nurses decreased by 21.4 .

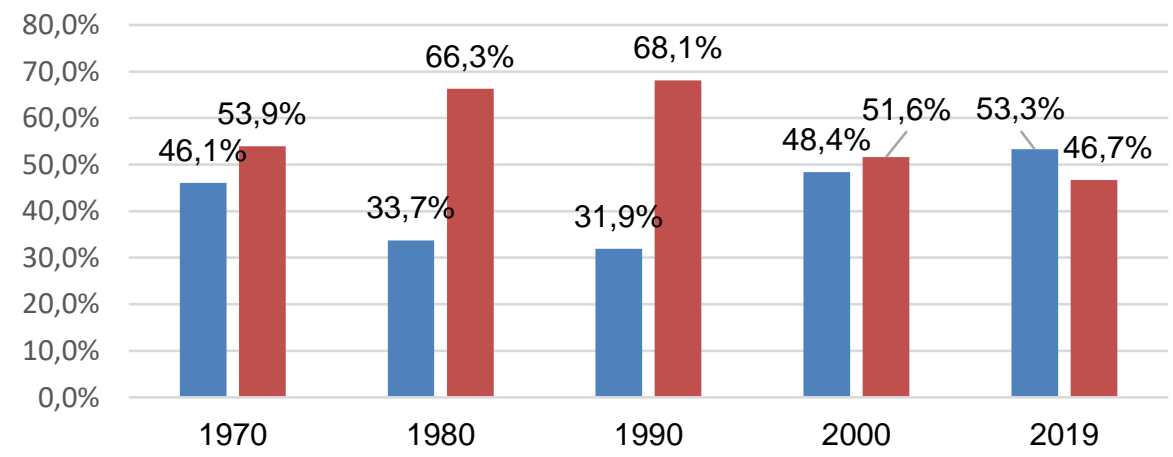

Fig.3. Trend of nurses decrease in rural area. 
Summary of group discussion. In rural areas, nursing is influenced by many factors. These include: Increased wages and benefits in remote rural areas, adequate human resources to reduce workload and streamline job descriptions, focus on retraining, nurse training, program optimization at the local level, professional degrees and specialization, supply of tools and equipment, Improving the legal environment. In summarizing the findings of the study, there is a similar result of study, and the most pressing issues for nurses in the regions are salaries, workload, ABT, and improving the legal environment.

Table 2. Nurses' views on ways to address the issues:

\begin{tabular}{|c|c|c|c|}
\hline № & $\begin{array}{l}\text { Scope of the } \\
\text { problem }\end{array}$ & Challenges & Proposed action \\
\hline 1 & Work load & $\begin{array}{l}\text { The workload of } \\
\text { nurses working in } \\
\text { rural areas is high }\end{array}$ & $\begin{array}{l}\text {-Balancing workload, reducing nurse workload } \\
\text {-Optimizing the nurse's work schedule } \\
\text { - Reduce workload } \\
\text { - Improving public perceptions and attitudes about } \\
\text { nursing } \\
\text { - Provide supportive management, understand and } \\
\text { support nurses at the management level }\end{array}$ \\
\hline 2 & $\begin{array}{l}\text { Working } \\
\text { conditions }\end{array}$ & $\begin{array}{l}\text { The working } \\
\text { environment and } \\
\text { conditions of nurses } \\
\text { working in rural } \\
\text { areas are poor }\end{array}$ & $\begin{array}{l}\text { - Improving the supply of modern tools and equipment } \\
\text { - To ensure safe working conditions for nurses supply of } \\
\text { disposable nursing equipment, } \\
\text { - Addressing nursing social issues. }\end{array}$ \\
\hline 3 & Training & $\begin{array}{l}\text { Retraining of nurses } \\
\text { working in rural } \\
\text { areas is insufficient }\end{array}$ & $\begin{array}{l}\text { - Systematic improvement of nursing education } \\
\text { - Skills training, } \\
\text { - Continuous development of nursing professionals } \\
\text { - To train a large number of specialized nurses, } \\
\text { - Stable operation }\end{array}$ \\
\hline 4 & $\begin{array}{l}\text { Human } \\
\text { resources }\end{array}$ & $\begin{array}{l}\text { Insufficient human } \\
\text { resources }\end{array}$ & $\begin{array}{l}\text { - Define human resource policy correctly, monitor } \\
\text { implementation } \\
\text { - Plan, develop and sustain human resources based on } \\
\text { STD standards, } \\
\text { - Increase the number of nurses at the local level, } \\
\text { - Hiring nurses and paramedics. } \\
\text { - Optimize the nurse-patient ratio. } \\
\text { - Distribute and place newly graduated nurses in rural } \\
\text { areas }\end{array}$ \\
\hline 5 & $\begin{array}{l}\text { Care } \\
\text { standards }\end{array}$ & $\begin{array}{l}\text { The implementation } \\
\text { of STD standards is } \\
\text { insufficient and the } \\
\text { quality of STDs is } \\
\text { poor in rural areas }\end{array}$ & $\begin{array}{l}\text { - The nursing care system needs to be changed to ensure } \\
\text { equal access } \\
\text { - Improving compliance with STD standards } \\
\text { - Need to develop home nursing } \\
\text { - Training in teamwork skills } \\
\text { - Improve monitoring of nurse performance } \\
\text { - Ensuring the quality of STD refinement and } \\
\text { development }\end{array}$ \\
\hline 6 & $\begin{array}{l}\text { Job } \\
\text { evaluation }\end{array}$ & $\begin{array}{l}\text { The evaluation of } \\
\text { the work of nurses } \\
\text { working in rural } \\
\text { areas is unrealistic }\end{array}$ & $\begin{array}{l}\text { - Optimize job descriptions } \\
\text { - Change the salary chain, increase salaries, pay by } \\
\text { education gap } \\
\text { - Providing regional allowances } \\
\text { - Provide real incentives } \\
\text { - Improvement of job evaluation objectively optimize } \\
\text { allocation }\end{array}$ \\
\hline
\end{tabular}

According to our survey, 40.7 percent of nurses working in rural areas are dissatisfied. 44.0 percent said that the workload of nurses working in rural areas was very high and 39.3 percent said that they were overworked. Underemployment, overwork, and increased overtime contribute to 
dissatisfaction among nurses, and the survey found that most of their working hours (over 80.0 percent) were spent on injections. In rural areas, 49 percent of nurses said that their productivity was not realistically assessed, and 83.1 percent said that it was not enough.

Employee dissatisfaction and suicidal ideation are directly related to high turnover, and the lower the employee's level of satisfaction, the higher the risk of dismissal.

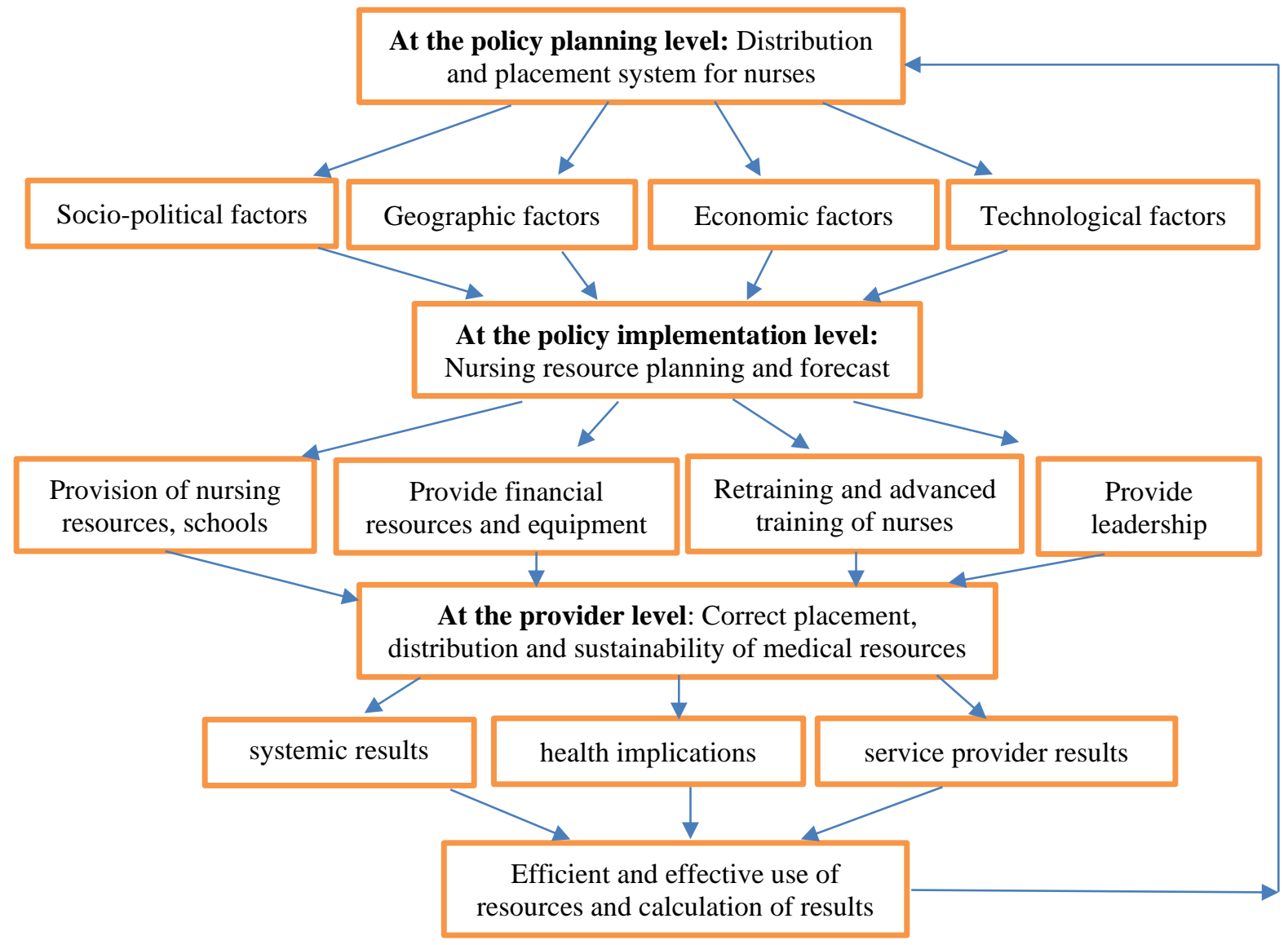

Fig.4. Types of nursing human resource placement systems

Based on the factual research, we have developed a system for allocating and allocating nursing resources, how political, socio-economic and technological factors affect it, forecasting the future of human resources, training a sufficient number of nurses, how to place and allocate them, stable employment and nursing care. A unified model has been developed to take into account the results of quality service delivery. The analysis of the implementation of the policy document shows that human resource policies and strategies are slow to be implemented, there is no analysis of the causes and effects to determine who is weak, there is no duplication of functions, and the parties do not know how to participate in cross-sectoral policy. Cooperation is weak and policies are not implemented from the top down.

Conclusions. There is a need for a policy to modernize Mongolia's nursing care in rural areas, and to allocate and retain nurses. Although the legal environment is in place, implementation has been slow and needs to be further improved. Nursing human resource growth is averaging 2.01 percent per year. The number of nurses working in rural areas has decreased by 21.4 percent over the last 19 years. There is a need to reflect cross-sectoral cooperation and the roles, activities and participation of policy stakeholders in the implementation of nursing human resource policy.

\section{REFERENCES}

1. Global health workforce alliance. Synthesis paper of the thematic working groups Health Work Force 2030 - towards a global strategy on human resources for health. 2015. pp. 1-40.

2. Ameryoun A, Meskarpour-Amiri M, Dezfuli-Nejad ML, Khoddami-Vishteh HR, Tofighi S. The assessment of inequality on geographical distribution of non-cardiac intensive care beds in Iran. Iran $\mathbf{J}$ Public Health. 2011;40(2):25-33. 
3. Mongolian Statistical Information Service. Available from: http://www.1212.mn/

4. The Ministry of Health, Mongolia; Health Indicators 2006-2019. Available from: http://www.chd.mohs.mn/

5. Dorjdagva J, Batbaatar E, Dorjsuren B, Kauhanen J. Income-related inequalities in health care utilization in Mongolia, 2007/2008-2012. Int J Equity Health, 2015;14:57.

6. Asian Development Bank. Program performance evaluation report in Mongolia. Available from https://www.adb.org/

7. The Ministry of Health Mongolia. Minister of Health Decree No 446 The Year 2009 Health Sector Human Resource Development Policy (Эрүүл мэндийн сайдын 2009 оны 443 тоот тушаал). Available from: http://ethics.mohs.mn/.

8. World Health Organization (WHO) Health workforce requirements for universal health coverage and the sustainable development goals 2016.

9. The Minister of Health Mongolia: Minister of Health Decree No 81 The Year 2004 Regulation of remote ambulance service (Эрүүл мэндийн сайдын 2004 оны 81 тоот тушаал) in Mongolian [Internet]. Available from: http://www.legalinfo.mn/

10. The Minister of Health Mongolia: Minister of Health Decree No. 162 The Year 2012 the Rotational procedure of Medical Profession (Эрүүл мэндийн сайдын 2012 оны 162 дугаар тоот тушаал: Эмнэлгийн мэргэжилтнийг сэлгэн ажилуулах журам) in Mongolian. 2012. Available from: http://www.mohs.mn/

11. World Health Organization (WHO) Increasing access to health workers in remote and rural areas through improved retention. Sci York [Internet] 2010; 23:3-69.

12. Tangcharoensathien V, Limwattananon S, Suphanchaimat R, Patcharanarumol W, Sawaengdee K, Putthasri W. Health workforce contributions to health system development: a platform for universal health coverage. Bull World Health Organ 2013; 91:874-880.

13. The government of Mongolia: Constitutional Law. Law of Health (Монгол Улсын Засгийн Газар; Эрүүл мэндийн тухай хууль) in Mongolian. Mongolia; Available from http://www.legalinfo.mn/

14. The government of Mongolia. The government of Mongolia Decree No. 150 The Year 2012 The system of additional incentives and cash bonuses for Medical professions (Засгийн Газрын 2012 оны 150 дугаap тогтоол). Available from: http://www.legalinfo.mn/ 